\title{
Sporadic Burkitt Lymphoma
}

National Cancer Institute

\section{Source}

National Cancer Institute. Sporadic Burkitt Lymphoma. NCI Thesaurus. Code C27914.

A clinical variant of Burkitt lymphoma that occurs throughout the world. It affects both children and adults and is more frequently seen in males. 